\title{
László Gozmány's annotated essay on the history of Hungarian lepidopterology published in 1949
}

\author{
Zsolt BÁLINT \\ Hungarian Natural History Museum, Department of Zoology, \\ H-1088Budapest, Baross utca 13., Hungary.E-mail: balint.zsolt@nhmus.hu
}

\begin{abstract}
In 1949, the American Lepidopterists' Society published an essay of nine entries on the history of Hungarian lepidopterology. The principal author of the short paper was the young, 28 years old Dr. László Gozmány. Access of the essay is difficult as early volumes of the News of the Lepidopterists' Society are rare in libraries and not available on the world-wide-web. The original essay is reproduced here with 38 supplementary annotations giving more historical clarity. The article is a tribute to Dr. László Gozmány on the occasion of the $100^{\text {th }}$ anniversary of his birth. With one figure.
\end{abstract}

Keywords - amateur lepidopterists, Calvinist pastors, Hungarian Natural History Museum, insect dealers, Jesuits, travellers

\section{INTRODUCTION}

The American Lepidopterists' Society was founded in 1947 on the principles of uniting amateurs and professionals in the scientific study of Lepidoptera. In the second membership list of the Society published in September 1948 one can find the name "Gozmány, Lancelot A. (Dr.)". This suggests that Dr. Gozmány had a solid connection with American colleagues who promptly informed him about the formation of the new society. His relationships were so good that he could join the society from the very beginnings.

The Society launched in print what was at first a newsletter of eight issues per year, entitled News of the Lepidopterists'Society. The policy of the News' editor J. E. Remington was to give information on the state of Lepidoptera research as widely as possible, and post-war Europe was especially an early focus. Hence, already in the early News volumes there were four essays from the pen of the young Dr. Gozmány. The first one was a short faunistical introduction on the marshlands (GozmÁNY 1948), then a technical paper (GozmÁNy 1949a). An overview of the zoogeographical elements of the Carpathian Basin (GozmÁNY 1949b) was 
presented as a continuation of a historical paper written in co-authorship with Gyula Lengyel, an amateur lepidopterist (GOzM ÁNY \& LENGYEL 1949). But the flow of Gozmány's essays soon stopped, as later we cannot find anything from him on the pages of the News. The icy climate of the Cold War froze Gozmány's writings to America (Fig. 1).

Although these essays published in the News are listed by BÁLINT et al. (2011), they are practically unknown outside the USA. In Hungary they are available only in the special Lepidoptera library of the Hungarian Natural History Museum where the early stencil volumes of News are bound and can be found under the inventory number EcF4 (after the first years the News was printed and not stencil copied). Even now in the world-wide-web none of them are available yet, as the earliest digitized volumes of the News which can be read on the homepage* of the society begin only from 1959.

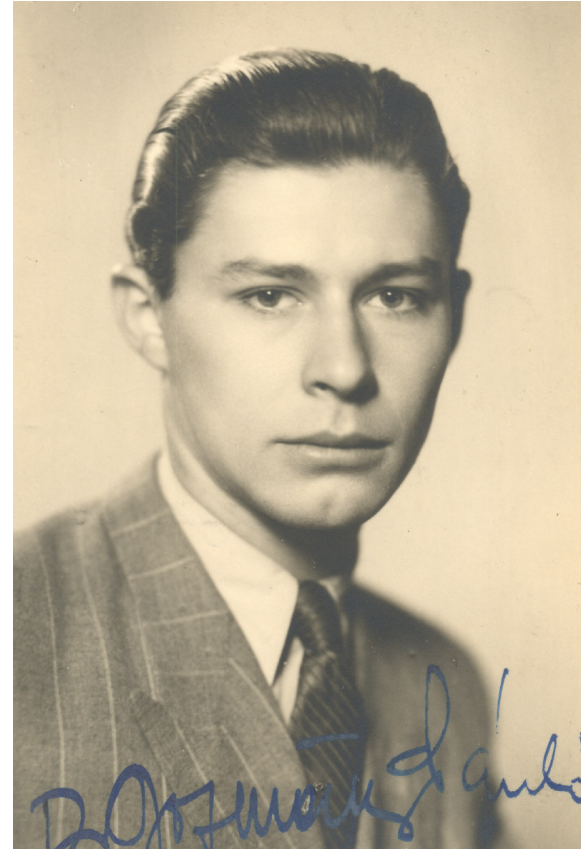

Figure 1. The portrait and signature of the young László Gozmány (Hungarian Natural History Museum, Library, Archives of Science History)

The text of GozMÁnY \& LENGYeL (1949) was scanned and transcribed with the use of the program Adobe Acrobat DC for the purpose of the present paper. The text is taken verbatim according to the original. Annotations (numbers presented between square brackets) are given for historical clarity presenting data taken from ABAFI-AIGNER (1898), SZABÓKy (2007), BÁlint \& FRIVALDSZKY (2009), BÁLINT \& Katona (2013), and Vig (2019). In these publications further relevant historical details can be traced.

With the publication of Gozmány's writing on the history of Hungarian lepidopterology, Iintend tocommemorate the $100^{\text {th }}$ anniversary of his birth. With this publication I would like to draw attention to the special renaissance personality of Dr. Gozmány, who united a person highly qualified not only in the fields of linguistics, jurisprudence and entomology, but also in the history of sciences. And finally, with this paper I would like to thank him personally for his work for lepidopterology, especially for the Lepidoptera Collection of the Hungarian Natural History Museum.

* https://www.lepsoc.org/content/news 


\section{HUNGARIAN LEPIDOPTEROLOGY- A SHORT HISTORY [1]}

Hungary, in the $15^{\text {th }}, 16^{\text {th }}$, and $17^{\text {th }}$ Centuries, was in a perpetual military turmoil. In this borderland of Europe where German, Turkish, and other inimical forces fought incessantly there remained only a few remote corners where the fire, or rather candlelight, of science burned. It is easy to understand that only when a Hungarian could have time for other thoughts than the problem of his mere survival was he able to take up that worn thread of culture which was so long lost after the death of King Matthias Corvinus late in the $15^{\text {th }}$ Century.

We can find, however, the first traces of entomological interest in the first half of the $17^{\text {th }}$ Century, when a small paper by one Andrew Horvath [2] was published, - in Latin, according to the time - dealing with insects under the title: "Disputatio Physica de Insectis". This paper is insignificant aside from its earliness in treating the subject. We can skip over other authors, such as G. Miskolczi, [3] I. Segesvári, [4] J. Conrad, [5] to Charles Turzer, [6] who in 1792 published a lepidopterological paper, in Linnaeus' system, on the fauna of his village and its environs in northern Hungary, with the surprisingly modern wish that also other naturalists publish their observations made in other territories in order to have a clear view of our fauna in later times. A year after Turzer's information, the major work of M. Piller [7] and Ch. Mitterspacher, [8] University professors of Nagyszombat, [9] published under the sonorous title "Iter per Poseganam Slavoniae Provinciam mensibus Junio et Julio Anno 1792 Susceptum", described their natural historical explorations in Com. Pozsega, [10] giving an account of the capture of 35 species of butterflies. [11]

John Grossinger, [12] Jesuit, wrote five volumes on "Universa Historia Physica Regni Hungariae Secundum Tria Regna Naturae Digesta", published in 1794-1797. We can note the influence of Linnaeus' immortal activities on the works of these people, writing of their scientia amabilis, issuing scores of books one after the other. Grossinger's work deals with Lepidoptera in its $4^{\text {th }}$ volume, inventing Hungarian names for the commoner species; in this his work is also of linguistic-historical interest.

We turn now to peculiar times. In the Western European states, with their scarcer fauna, the zealous entomological amateurs have also in their ranks collectors who exhibit a more mercenary sense than the others. For a long time men dominated entomology who refused to publish or reveal their "secret" collecting data and methods for fear of competition. These people came to the rich and still mainly unexplored Hungarian entomological Eldorado: Germans, Czechs, and others. Some names for case of reference are: Koy, [13] Böhm, [14] Haberhauer, [15] Kindermann, [16] Dahl, [17] Stentz, [18] and the two Ankers, [19] none of whom contributed anything to real science, with the possible exception of the Ankers brothers. [20]

Turning away from this era we come to our ablest lepidopterist: Imre Frivaldszky. Born in 1799, eventually a physician, he was an indefatigable lover of 
Lepidoptera. He showed the way for later collectors and entomologists in Hungary with his discoveries of new collecting places and special Hungarian habitats, his numerous monographs, his descriptions of new species, and his scientific working methods. His great work, a complete informative manual on Hungary's fauna, was never finished, but he did publish a gem: "Characteristic Data in the Hungarian Fauna". He collected in the whole country in the years 1833-1870, organizing and nurturing a host of new acolytes to the science. Member or the Academy of Sciences, and Keeper of the Entomological Department of the Hungarian Natural History Museum, he did more for Hungarian lepidopterology than all his numerous contemporaries and all predecessors. [21]

L. Abafi-Aigner [22] gave the next momentum to Hungarian lepidopterology. He was a great publisher and his quill gave birth to hundreds of articles on every aspect of his science. In 1896 he compiled the "Catalogue of Hungarian Butterflies and Moths" from the 8 zoogeographical regions of the country. [23] He also wrote the first good manual and determining book, with about 50 colored plates. [24] He collected throughout the country, and according to custom described numerous aberrations. At this time the first Hungarian entomological periodical, Rovartani Lapok, was established as a suitable place to exchange observations and to publish papers. As the sole entomological review, it dealt with other insect orders also, but lepidopterists were in absolute majority, and it can be justly called a lepidopterological periodical. Its editor was Abafi-Aigner.

Let us deviate now for a moment to mention the veritable host of foreign scientists and collectors who came to Hungary, sometimes returning yearly to collect and explore her lepidopterous treasures. We can only mention a few celebrities: Hübner, [25] Rebel, [26] Staudinger, [27] names now immortal. Baron Rothschild [28] had his own private collector, Predota, [29] here, specially commissioned to collect in the Great Plains and southern parts of Hungary. [30] M. Fontaine published her diary in the Entomologist, written during her Hungarian collecting in our classical haunts, remembering hospitality and the cordiality of the scientists who accompanied her on the collecting trips. [31]

In 1894, the Entomological Bureau [32] was established, dealing with applied agri-, horti-, and silvicultural entomology. Its chief was J. Jablonowszky, [33] who was also one of the chief tycoons of the Entomological Society [34], together with A. Schmidt, the successor of Abafi-Aigner as Keeper of the Lepidoptera Department of the Museum. [35] He was chiefly a biologist but also a good faunistical explorer. Jablonowszky was followed by Gy. Kadocsa, [36] still the President of the Society, whose great knowledge and sure judgment made him the natural leader of our circle.

Now, after the war, we are trying hard to resuscitate the life of our esteemed science, with the help of Dr. L. Kovács, [37] specialist of Agrotidae, Dr. L. Issekutz, [38] specialist of Zygaenidae and Parnassiidae, and other zealous colleagues. 


\section{ANNOTATIONS}

[1] The paper was written in co-authorship of Dr. Julius [Gyula] Lengyel (1891-1968); physician, a well-known and highly respected amateur lepidopterist; in the time when the paper was written he was resided in Budapest and certainly was in good terms with the young Dr. Gozmány.

[2] Andreas Horvat [Horvát András] (? - ?); Calvinist pastor; his Disputatio Physica de Insectis was published in Wittenberg in 1637.

[3] Gaspar Miskolczi [Miskolczi Gáspár] (1628-1696); Calvinist pastor; his book Egy Jeles Vad-Kert [The Prominent Menagerie] was published in Löcse (now Levoča, Slovakia) in 1702.

[4] Istvan Segesvari [Segesvári István] (1762-1826); physician in Debrecen, he translated to Hungarian the work of Derham William (1657-1753) PhysicoTheology: or a Demonstration of the Being and Attributes of God, from his Works of Creation, published in 1713 .

[5] Joseph Conrad [Conrád József] (1756-1780); one of the first entomologists in Hungary, already used the Linnean binominal nomenclature in print.

[6] Karl Turzer [Turzer Károly] (? - ?); landlord in County Bars (now Slovakia).

[7] Matthias Piller [Piller Mátyás] (1733-1788); Jesuit priest before the dissolution of the order Society of Jesus (1773), teacher of the Theresianum (Vienna), then in the university of Pest.

[8] Ludwig Mitterpacher [Mitterpacher Lajos] (1734-1814); Jesuit priest before the dissolution of the order, teacher in the Theresianum (Vienna), then in the university of Pest.

[9] Nagyszombat = Turnau, Trnava (now Slovakia); in the Hungarian Kingdom the Society of Jesus run a University in Nagyszombat, where entomology had been also practiced and a large insect collection was assembled.

[10] Pozsega vármegye $=$ County Pozsega was a part of Slavonian Crotia ruled by the Hungarian Crown.

[11] The actual number of Lepidoptera is 29 , covering 11 butterfly and 18 moth species.

[12] Johannes Grossinger [Grossinger János] (1728-1803); Jesuit priest, after the dissolution of the order a diocesan priest.

[13] Tobias Koy [Koy Tóbiás] (1757-1829); royal court treasuer and amateur entomologist, active in the Budapest region; the catalogue of his collection was published in 1800 .

[14] Moritz Johann Böhm [Böhm József] (?-1809); royal court officer; close friend of Koy; his observations recorded by his diary became published posthumously at the end of the $19^{\text {th }}$ century.

[15] Joseph Haberhauer [Haberhauer József] (1828-1902); traveler and insect dealer; visited Persia, the Caucasus region, and lived in Rumelia (Bulgaria). 
[16] Senior (?-1857) and Junior (1810-1860) Adalbert Kindermann [Kindermann Albert]; travellers and insect dealers; visited many times the Balkans, the Caucasus, the Volga regions and Siberia.

[17] Georg Dahl [Dahl György] (1769-1831); personal servant of count Johann Centurius Hoffmansegg during his travels in Hungary; later Vienna-based insect dealer; visited many times southern Hungary and Croatia.

[18] Albert Stentz (?-1877); Vienna-based insect dealer, who collected mainly in the countries of the Hungarian Crown (Croatia, Dalmatia, Hungary, Transylvania), in business competitor of G. Dahl and the Kindermanns.

[19] Ludwig Anker [Anker Lajos] (1822-1887) and Rudolf Anker (1824-1901); passionate collectors and discoverers of legendary Hungarian species as Chondrosoma fiduciaria Anker, 1854, Erannis ankeraria (Staudinger, 1861), Oxytripia orbiculosa (Esper, 1799), etc.

[20] This is an unusual subjective statement. In Hungary Böhm and Koy contributed the first technical papers on entomology in print. Dahl, Haberhauer, the Kindermanns, and Stentz all were primarily collectors and dealers, as the Anker brothers; and similar to the Ankers they did not paid too much attention to formulate their experiences and observations into published papers.

[21] Imre Frivaldszky (1799-1870); academian, curator of the natural history collections of the Hungarian Natural History Museum; pioneer explorer of the Balkan flora and fauna.

[22] Ludwig (Lajos) Abafi-Aigner (1840-1909); publisher, librarian and entomologist; in the eve of his life he worked as a technician beside János Pável (1841-1901) in the Hungarian Natural History Museum.

[23] Abafi-Aigner et al. 1896.

[24] Abafi-Aigner L. 1907. In Berge's book there were 50 plates, however Abafi's book provided one supplementary plate for showing typical Hungarian species not discussed in the German original.

[25] Jakob Hübner (1761-1821); engraver; published a series of books on European Lepidoptera; in those works many species had been described from the Pannonian region and the Carpathian Basin.

[26] Hans Rebel (1861-1940); curator of entomology, then director general of the Naturhistorisches Museum, Wien; he visited Hungary several times and was active in elaborating material collected there; on Lepidoptera subjects Rebel was in tight relationship with Antal Schmidt, curator in the Hungarian Natural History Museum between the period of 1906-1936 (see below).

[27] Otto Staudinger (1830-1900); entomologist, publisher and owner of a large firm dealing natural history items; he acquired important Lepidoptera material originated from Hungary by various collectors. 
[28] Nathaniel Charles Rothschild (1877-1923); banker and entomologist, pioneer in nature conservation; he married Rózsika Edle von Wertheimstein (1870-1940) born in Nagyvárad (now Oradea, Romania); usually the family spent the summers in Hungary and intensively collected lepidopterans and other insects.

[29] Karl Predota [ Predota Károly] (1872-1962); Vienna-based professional insect collector.

[30] Southern parts of Hungary = the Banat region, vicinity of Hekulesfürdö and Mehádia (now Romania, Băile Herculane and Mehadia) and the sand region of Deliblát (now Serbia).

[31] Margaret Elizabeth Fountaine (1862-1940); traveller and diarist, passionate butterfly collector.

[32] Magyar Királyi Rovartani Állomás.

[33] József Jablonowski (1863-1943); entomologist, worked successfully in the field of plant protection.

[34] Magyar Rovartani Társaság.

[35] Anton Schmidt [Schmidt Antal] (1880-1962); first appointed curator of Lepidoptera in the Hungarian Natural History Museum.

[36] Gyula Kadocsa (1880-1962); entomologist, worked successfully in the field of plant protection.

[37] Lajos Kovács (1900-1971); archivist, after the political changes of 1948 he was employed as research entomologist in the Hungarian Natural History Museum; he worked chiefly on Macrolepidoptera faunistics and noctuid taxonomy.

[38] László Issekutz (1893-1973); lawyer, after 1948 worked first in the Hungarian Natural History Museum as volunteer, then as scholar supported by a grant provided by the Hungarian Academy of Sciences; after the 1956 events he immigrated to Austria.

Acknowledgements - I thank to my colleague Mr. Gergely Katona for scanning and transcribing the text, and beside him to Dr. Balázs Tóth, Dr. Zoltán Vas and Dr. John Heppner (USA) for their review comments. Mrs. Angéla Matuszka provided the portrait of the young Dr. Gozmány. Thanks are also due to her. 


\section{REFERENCES}

Abafi Aigner L. 1898: A lepkészet története Magyarországon. [The history of lepidopterology in Hungary.] - A Kir. Magyar Természettudományi Társulat, Budapest, VI + 202 pp.

Abafi-Aigner L. 1907: Magyarország lepkéi. Tekintettel Európa többi országainak lepkefaunájára. A Berge-féle lepkekönyv képeivel. [Lepidoptera of Hungary. In regards to the Lepidoptera fauna of other European countries. With the plates of Berge's Lepidoptera book.] - Királyi Magyar Természettudományi Társulat, Budapest, 137 pp., 51 pls.

Bálint Zs. \& ID. Frivaldszy K J. 2009: A Magyar Parnasszuson. Frivaldszky Imre (1799-1870) a természet kutatója. [On the Hungarian Parnassus. Imre Frivaldszky (1799-1870), the naturalist.] - Magyar Természettudományi Múzeum, Budapest, 243 pp., figs.?

Abafi-Aigner L., PÁvel J. \& Uhryk N. 1896: Fauna Regni Hungariae. Animalium Hungariae Hucusque Cognitorum Enumeratio Systematica In Memoriam Hungariae Mille Abhinc Annis Constituti. III. Arthropoda. Insecta. Ordo Lepidoptera. - Királyi Magyar Természettudományi Társulat, Budapest, 82 pp.

BÁlint Zs. \& Katona G. 2014: Lepkeírások. [Lepwritings.] - Széchenyi Zsigmond Könyvtár, Hatvan, 91 pp.

Bálint Zs., Katona G. \& Kun A. 2011: The scientific publications of Dr László Gozmány (1921-2006) on Lepidoptera with a revised bibliography and an annotated list of taxon names he proposed. - Annales historico-naturales Musei nationalis hungarici 103: 373-428.

CsıKı E. 1916: Egy régi rovartani munkáról. [On an old entomological work.] - Rovartani Lapok 23(1-2): 7-15.

GozmÁny L. 1948: A survey of the helophilous macro-moths of the Hungarian moorlands. - The Lepidopterists' News 2(8): 93-94.

Gozmány L. 1949a: Technique notes: Baiting for moths. -The Lepidopterists' News 3(3): 26.

Gozmány L. 1949b: Hungarian lepidopterology. The Lepidoptera fauna of the Carpathian Basin. - The Lepidopterists' News 3(7): 75-76.

Gozmány L.\& Lengyel Gy. 1949: Hungarian lepidopterology I. A short history. - The Lepidopterists' News 3(4-5): 43.

Szaвóкy Cs. 2007: A lepkészet története Magyarországon. [The history of lepidopterology in Hungary.] - Magánkiadás, Budapest, 415 pp., + map.

Vig K. 2019: A rovartani kutatások története Magyarországon. [The history of entomological studies in Hungary.] - Savaria Megyei Hatókörű Városi Múzeum, Szombathely, 727 pp. 


\title{
Gozmány László jegyzetekkel kiegészített, 1949-ben megjelent esszéje a magyar lepkészet történetéröl
}

\author{
BÁLINT ZsolT
}

Magyar Természettudományi Múzeum, Állattár,

H-1088, Budapest, Baross utca 13., Magyarország.E-mail: balint.zsolt@nhmus.hu

Összefoglalás - 1949-ben az amerikai Lepidopterists' Society hírlevelében kilenc bekezdésből álló esszét jelentetett meg a magyar lepkészet történetéről. A rövid dolgozat első szerzője a fiatal, 28 éves Dr. Gozmány László volt. Az esszé hozzáférhetősége körülményes, mivel a folyóirat korai kötetei a könyvtárakban ritkák és a világhálón sem elérhetők. Az eredeti esszét itt közlöm 38 kiegészítő megjegyzéssel, amelyek az írásnak mélyebb történelmi összefüggéseket kínálnak. A cikk tisztelgés Dr. Gozmány László előtt, születésének századik évfordulójának alkalmából. Egy ábrával.

Kulcsszavak - amatőr lepkészek, jezsuiták, Magyar Természettudományi Múzeum, református lelkészek, rovarkereskedők, utazók

\section{ÁBRAALÁÍRÁS}

1. ábra: A fiatal Gozmány László arcképe és aláírása (Magyar Természettudományi Múzeum, Könyvtár, Tudománytörténeti Archívum) 